\title{
The Influence of Grapevine Cultivar and Isolate of Eutypa lata on Wood and Foliar Symptoms
}

\begin{abstract}
M. R. Sosnowski, Cooperative Research Centre for Viticulture and South Australian Research and Development Institute, GPO Box 397, Adelaide, SA, 5001 Australia; R. Lardner, Cooperative Research Centre for Viticulture and Discipline of Plant and Food Science, School of Agriculture, Food and Wine, The University of Adelaide, Waite Campus, Glen Osmond, SA, 5064 Australia; T. J. Wicks, Cooperative Research Centre for Viticulture and South Australian Research and Development Institute; E. S. Scott, Cooperative Research Centre for Viticulture and Discipline of Plant and Food Science, School of Agriculture, Food and Wine, The University of Adelaide
\end{abstract}

\begin{abstract}
Sosnowski, M. R., Lardner, R., Wicks, T. J., and Scott, E. S. 2007. The influence of grapevine cultivar and isolate of Eutypa lata on wood and foliar symptoms. Plant Dis. 91:924-931.

Grapevine cultivar (Vitis vinifera) and isolate of Eutypa lata influence wood and foliar symptoms of Eutypa dieback. Foliar symptoms of Eutypa dieback developed within 8 months of inoculating young grapevines (cvs. Grenache, Cabernet Sauvignon, and Merlot) in a shadehouse. Isolates of $E$. lata from various wine regions in southern Australia varied in their ability to colonize inoculated grapevines and induce wood and foliar symptoms. Grapevine cultivars varied for wood and foliar symptom expression but not for mycelial colonization. However, the severity of foliar symptoms was not related to the rate of spread of the fungus in the grapevine. Furthermore, the staining of wood typically attributed to $E$. lata did not reflect the presence of the fungus because the fungus was detected up to $80 \mathrm{~mm}$ beyond the stain. A field trial with mature grapevines revealed significant differences in the rate of spread of wood staining due to E. lata among eight cultivars, with up to $50 \mathrm{~mm} /$ year detected in Cabernet Sauvignon and Shiraz grapevines. In the shadehouse, the maximum growth rate of $E$. lata was recorded to be $115 \mathrm{~mm} / \mathrm{year}$ for Grenache rootlings. Information from this study may help to optimize management strategies for maintaining productivity of grapevines with Eutypa dieback, thus reducing the economic impact of the disease.
\end{abstract}

Additional keyword: pathogenicity

Eutypa dieback is caused by the fungus Eutypa lata (Pers.) Tul. \& C. Tul. (= E. armeniacae Hansf. \& M.V. Carter) and affects grapevines (Vitis vinifera) in many cool-climate grape-growing regions of the world (5). It contributes to vineyard decline by reducing growth and yield $(6,16)$. In Australia, yield losses of at least 860 and $740 \mathrm{~kg} / \mathrm{ha}$ have been reported for Shiraz and Cabernet Sauvignon vineyards, respectively (24), and, in California, Eutypa dieback causes annual economic losses of up to U.S.\$260 million (20). In the vineyard, there is a delay between infection of grapevines and expression of symptoms of between 1 and 8 years $(4,14,22)$. This delay often impedes disease diagnosis and hinders research.

Corresponding author: M. R. Sosnowski

E-mail: sosnowski.mark@saugov.sa.gov.au

Accepted for publication 8 January 2007.

doi:10.1094/PDIS-91-8-0924

(C) 2007 The American Phytopathological Society
Grapevines become infected when ascospores of $E$. lata enter fresh wounds, caused by pruning or mechanical damage, and germinate in xylem vessels $(3,14)$. Mycelium of E. lata slowly colonizes the woody tissue and, if left unchecked, the entire grapevine may be killed within 10 years of initial infection (18). Wood symptoms include internal necrosis, visualized as a wedge-shaped area of stained tissue if a cross-section is made of an infected trunk or cordon, and external cankers which form around sites of infection $(5,9)$. Foliar symptoms, including stunted shoots with chlorotic leaves, often cupped and with tattered margins, are thought to be caused by toxic acetylenic phenol metabolites produced by the fungus in the wood and transported to the foliage $(15,22)$. More recently, Mahoney et al. (13) suggested that the metabolites react at the point of production, disrupting vascular structure and inhibiting transport of nutrients. There is considerable annual variation in symptom expression, with grapevines commonly displaying symptoms one year but not the next $(6,21)$.
Different cultivars of grapevine display varying severity of foliar symptoms of Eutypa dieback $(19,23)$ which may reflect differences in susceptibility to the disease. Cultivars differ in their susceptibility to infection by ascospores of E. lata (17); however, little is known about the growth rate of the fungus in grapevine wood or about the relative virulence of different isolates of E. lata to grapevine.

One current strategy for controlling Eutypa dieback is the removal of stained tissue, as well as 10 to $20 \mathrm{~cm}$ of healthy tissue beyond the staining $(7,9)$. However, this recommendation is based primarily on research on apricots (5), which are very susceptible to Eutypa dieback, and little is known about the colonization of grapevine tissue by E. lata.

In this study, we report on a technique developed to evaluate the infection of grapevine cuttings by E. lata in a shadehouse. The technique was used to examine pathogenic variation in a collection of Australian isolates of E. lata on three grapevine cultivars, with particular reference to differences in foliar symptoms and growth rate of the fungal isolates in woody tissue. We also conducted a field trial to assess the extent of wood staining induced by $E$. lata in mature grapevines.

\section{MATERIALS AND METHODS}

Shadehouse experiments. Rooted grapevine cuttings were obtained from a commercial nursery and planted in plastic bags ( 120 by 120 by $300 \mathrm{~mm}$; Poly Products Co.) filled with University of California (UC) potting mix (2) in September 2003. Three cultivars of $V$. vinifera were included; Grenache and Cabernet Sauvignon, which are highly susceptible to Eutypa dieback, and Merlot, which is resistant (8). Grapevines were transferred to benches in a shadehouse and hand watered as required.

In all, 40 isolates of $E$. lata and 8 isolates of other fungi commonly isolated from grapevine trunks were collected from wine regions throughout Australia (Table 1). Isolates were obtained from perithecia 
on mature wood or hyphae in infected trunks or cordons and were derived from individual ascospores or single hyphal tips. Isolates D022 and E1 had been stored in sterile distilled water at 3 to $4^{\circ} \mathrm{C}$ for over 20 years, and their pathogenicity was not known. Isolates were cultured on potato dextrose agar (PDA; Oxoid) at $23^{\circ} \mathrm{C}$ under fluorescent light (Phillips TLD 36W/865 cool daylight) for $12 \mathrm{~h}$ each day. Agar plugs ( $5 \mathrm{~mm}$ in diameter) containing mycelium were removed from the margins of actively growing cultures on PDA using a cork borer. Using a 5-mm-diameter drill bit, sterilized by dipping in ethanol and flaming between each sample, holes were drilled approximately 5 to $7 \mathrm{~mm}$ deep near the apex of the main stem of rootlings (one per rootling). Agar plugs were inserted into holes and sealed by wrapping with Parafilm (Pechiney Plastic Packaging, Chicago). Rootlings were watered twice daily in the week following inoculation to maintain stem moisture; then, watering continued as necessary to maintain soil moisture.

Two experiments were established using 768 rootlings. In experiment 1 , Grenache rootlings were inoculated 5 months after planting with 27 isolates of E. lata in February 2004 . In experiment 2 , all three cultivars were inoculated in February 2004 with 12 isolates of $E$. lata and 8 non- $E$. lata isolates. Noninoculated control rootlings, drilled and then either treated with a sterile PDA plug or left untreated, were included in both experiments. For each experiment, there were eight replicates per treatment, including the control treatments, and both experiments were arranged in a randomized block design. In April 2004 and 2005, shoots on rootlings were pruned to two buds to restrict the number of new shoots each season to facilitate management of rootlings and assessment of foliar symptoms. Foliar symptoms were assessed in October 2004 and 2005, when asymptomatic shoots of control rootlings were 50 to $70 \mathrm{~cm}$ long. Severity of symptoms attributed to E. lata was expressed as the difference in length of stunted shoots on inoculated and control rootlings as a percentage of the length of shoots on control rootlings. In February 2006, 24 months after inoculation, four replicate rootlings per treatment were selected from each experiment (a total of 384 rootlings). Rootlings were removed from the soil before excising the roots and rinsing the cane with tap water to remove potting mix. Using a knife, bark was removed from each cane to expose any staining of the wood. The overall extent of stained wood then was assessed by measuring the distance of staining both above and below the inoculation point.

To determine the extent of spread of mycelium of $E$. lata beyond the inoculation point in each of the four replicates,

Table 1. Origin and source of fungal isolates used in this study

\begin{tabular}{|c|c|c|c|c|}
\hline Isolate number & Species & Source (cultivar) & Year of isolation & Origin $^{z}$ \\
\hline 1725 & Phaeomoniella chlamydospora & Vitis vinifera (Shiraz) & 1999 & Mildura, Vic \\
\hline 1739 & Phellinus punctatus & $V$. vinifera & 2000 & Vic \\
\hline 1740 & Phellinus sp. & $V$. vinifera & 2000 & WA \\
\hline 1765 & Botryosphaeria ribis & $V$. vinifera & 2000 & Vic \\
\hline 1776 & Eutypa lata & V. vinifera & 2000 & SA \\
\hline $200 / 3$ & E. lata & $V$. vinifera & 2002 & McLaren Vale, SA \\
\hline 69484 & Libertella sp. & $V$. vinifera & 2001 & Hunter Valley, NSW \\
\hline 83330 & E. lata & Prunus persica & 1983 & SA \\
\hline B001 & E. lata & V. vinifera (Shiraz) & 2000 & Barossa Valley, SA \\
\hline B002 & E. lata & V. vinifera (Shiraz) & 2000 & Barossa Valley, SA \\
\hline B003 & E. lata & V. vinifera (Shiraz) & 2000 & Barossa Valley, SA \\
\hline B005 & E. lata & V. vinifera (Shiraz) & 2000 & Barossa Valley, SA \\
\hline $\mathrm{C} 001$ & E. lata & V. vinifera (Cabernet Sauvignon) & 2000 & Clare, SA \\
\hline $\mathrm{C} 002$ & E. lata & V. vinifera (Chardonnay) & 2000 & Clare, SA \\
\hline $\mathrm{C} 003$ & E. lata & V. vinifera (Riesling) & 2000 & Clare, SA \\
\hline DO22 & Botryosphaeria sp. & V. vinifera (Cabernet Sauvignon) & Unknown & McLaren Vale, SA \\
\hline E1 & E. lata & V. vinifera & Unknown & SA \\
\hline H001 & Cryptovalsa ampelina & $V$. vinifera & 2000 & Coonawarra, SA \\
\hline L001 & E. lata & V. vinifera (Cabernet Sauvignon) & 2000 & Loxton, SA \\
\hline L002 & E. lata & V. vinifera (Chenin Blanc) & 2000 & Loxton, SA \\
\hline L003 & E. lata & V. vinifera (Chenin Blanc) & 2000 & Loxton, SA \\
\hline LO19 & Phaeoacremonium aleophilum & V. vinifera (Muscat Ottonel) & 2000 & Loxton, SA \\
\hline M279 & E. lata & Prunus armeniaca & 1999 & Vic \\
\hline M280 & E. lata & V. vinifera & 1999 & Vic \\
\hline M295 & E. lata & $V$. vinifera & 1999 & Vic \\
\hline M302 & E. lata & $V$. vinifera & 1999 & Vic \\
\hline M335 & E. lata & $V$. vinifera & 1999 & Vic \\
\hline MA002 & E. lata & $V$. vinifera (Shiraz) & 2003 & McLaren Vale, SA \\
\hline MA019 & E. lata & $V$. vinifera (Shiraz) & 2003 & McLaren Vale, SA \\
\hline MA076 & E. lata & $V$. vinifera (Shiraz) & 2003 & McLaren Vale, SA \\
\hline MA089 & E. lata & V. vinifera (Shiraz) & 2003 & McLaren Vale, SA \\
\hline MA101 & E. lata & V. vinifera (Shiraz) & 2003 & McLaren Vale, SA \\
\hline MA176 & E. lata & V. vinifera (Shiraz) & 2003 & McLaren Vale, SA \\
\hline N04 & E. lata & $V$. vinifera & 2000 & Nuriootpa, SA \\
\hline OR008 & E. lata & $V$. vinifera (Shiraz) & 2003 & Coonawarra, SA \\
\hline OR019 & E. lata & V. vinifera (Shiraz) & 2003 & Coonawarra, SA \\
\hline OR022 & E. lata & V. vinifera (Shiraz) & 2003 & Coonawarra, SA \\
\hline OR024 & E. lata & V. vinifera (Shiraz) & 2003 & Coonawarra, SA \\
\hline OR039 & E. lata & V. vinifera (Shiraz) & 2003 & Coonawarra, SA \\
\hline SS10 & E. lata & $V$. vinifera & 1981 & SA \\
\hline SS6 & E. lata & Viburnum opulus & 1984 & SA \\
\hline WB031 & E. lata & $V$. vinifera (Shiraz) & 2003 & Eden Valley, SA \\
\hline WB052 & E. lata & V. vinifera (Shiraz) & 2003 & Eden Valley, SA \\
\hline WB066 & E. lata & V. vinifera (Shiraz) & 2003 & Eden Valley, SA \\
\hline WB115 & E. lata & V. vinifera (Shiraz) & 2003 & Eden Valley, SA \\
\hline WB182 & E. lata & $V$. vinifera (Shiraz) & 2003 & Eden Valley, SA \\
\hline
\end{tabular}

${ }^{\mathrm{z}}$ Vic $=$ Victoria, $\mathrm{WA}=$ Western Australia, $\mathrm{SA}=$ South Australia, and NSW $=$ New South Wales. 
mycelium was isolated from all canes inoculated with E. lata, and from control rootlings treated with blank agar plugs, as follows. Each stem was surface sterilized in $2.5 \%$ sodium hypochlorite containing a drop of Tween 20 (Sigma-Aldrich, St. Louis) per $500 \mathrm{ml}$ of solution for $12 \mathrm{~min}$ and rinsed in sterile distilled water. Using pruning shears sterilized by dipping in ethanol and flaming, 2-mm sections were taken at 5- or 10-mm intervals above and below the inoculation point. This was done to a maximum of $100 \mathrm{~mm}$ beyond staining on each rootling and sections were transferred to PDA plates. Plates were incubated as described above and fungi subcultured onto PDA after 1 week. Two weeks later, cultures were identified as $E$. lata based on colony morphology. The identity of representative cultures was confirmed using DNA markers specific to E. lata (12).

All data were subjected to analysis of variance (Statistix for Windows v. 4.1: Tallahassee, FL). Differences among foliar symptoms (percent), length of stained vascular tissues, and maximum distance of colonization by mycelium of $E$. lata were compared for all isolates and cultivars.

Field experiment. Mature grapevines (4 Grenache; 10 each Merlot, Pinot Noir, Riesling, and Semillon; 14 Shiraz; 17 Cabernet Sauvignon, and 68 Gamay), planted between 1974 and 1991 and located at the Nuriootpa Research Centre (approximately
$100 \mathrm{~km}$ north of Adelaide, South Australia), were used for this experiment. Ascospore inoculum was prepared as described by John et al. (11) from dead grapevine wood bearing stromata of E. lata that had been collected from the vineyard floor. Five wounds were made on each grapevine by pruning 1-year-old wood to two bud spurs. Each wound was inoculated on the day of pruning with a $10-\mu$ d droplet containing 1,000 ascospores of E. lata suspended in water to simulate natural infection. Inoculations were made in September 2000 or August 2001. Grapevines were inspected for foliar symptoms early in the spring each year following inoculation. Inoculated spurs were removed in July 2004 and returned to the laboratory for assessment. Bark was removed to reveal the extent of stained wood and then spurs were dissected. The distance to which stained tissue extended from the inoculation point was measured. To confirm the presence of $E$. lata, tissue taken from the furthest point of staining in each sample was analyzed using an E. lata-specific DNA probe (12). Data from samples confirmed as containing $E$. lata were subjected to one-way analysis of variance (Statistix for Windows).

\section{RESULTS}

Shadehouse experiments. When assessed 8 months after inoculation, foliar symptoms were evident on some treated grapevines of each cultivar following inoculation with $E$. lata, but not on control grapevines or those inoculated with other species of fungi. Examples of symptomatic grapevines are given in Figure 1. Foliar symptoms were observed on shoots above the site of inoculation on all but three cuttings (two Grenache and one Cabernet Sauvignon); these cuttings had been inoculated with isolates M302, OR024, and WB066.

In experiment 1,8 months after inoculation, 24 of the 28 isolates of E. lata (all except B005, WB052, WB115, and M280) induced symptoms on at least one of the eight replicate Grenache cuttings (Fig 2A). Four isolates (B004, C001, L002, and WB031) induced foliar symptoms on at least $50 \%$ of the replicates. Depending on the isolate, the mean foliar symptom rating on Grenache ranged from 0 to $24 \%$.

In experiment 2,8 months after inoculation, 6 of the 12 isolates of E. lata induced foliar symptoms on at least one grapevine (Fig. 3A). Two of the six isolates (M302 and 1776) induced foliar symptoms on all three cultivars and one (200/3) induced symptoms on Grenache and Cabernet Sauvignon. Two isolates (M295 and M280) induced symptoms on Grenache only and one (N04) on Cabernet Sauvignon only. The mean foliar symptom rating for Grenache $(4.2 \%)$ was significantly greater $(P<$ $0.05)$ than that for Cabernet Sauvignon $(0.5 \%)$ or Merlot $(1.2 \%)$.
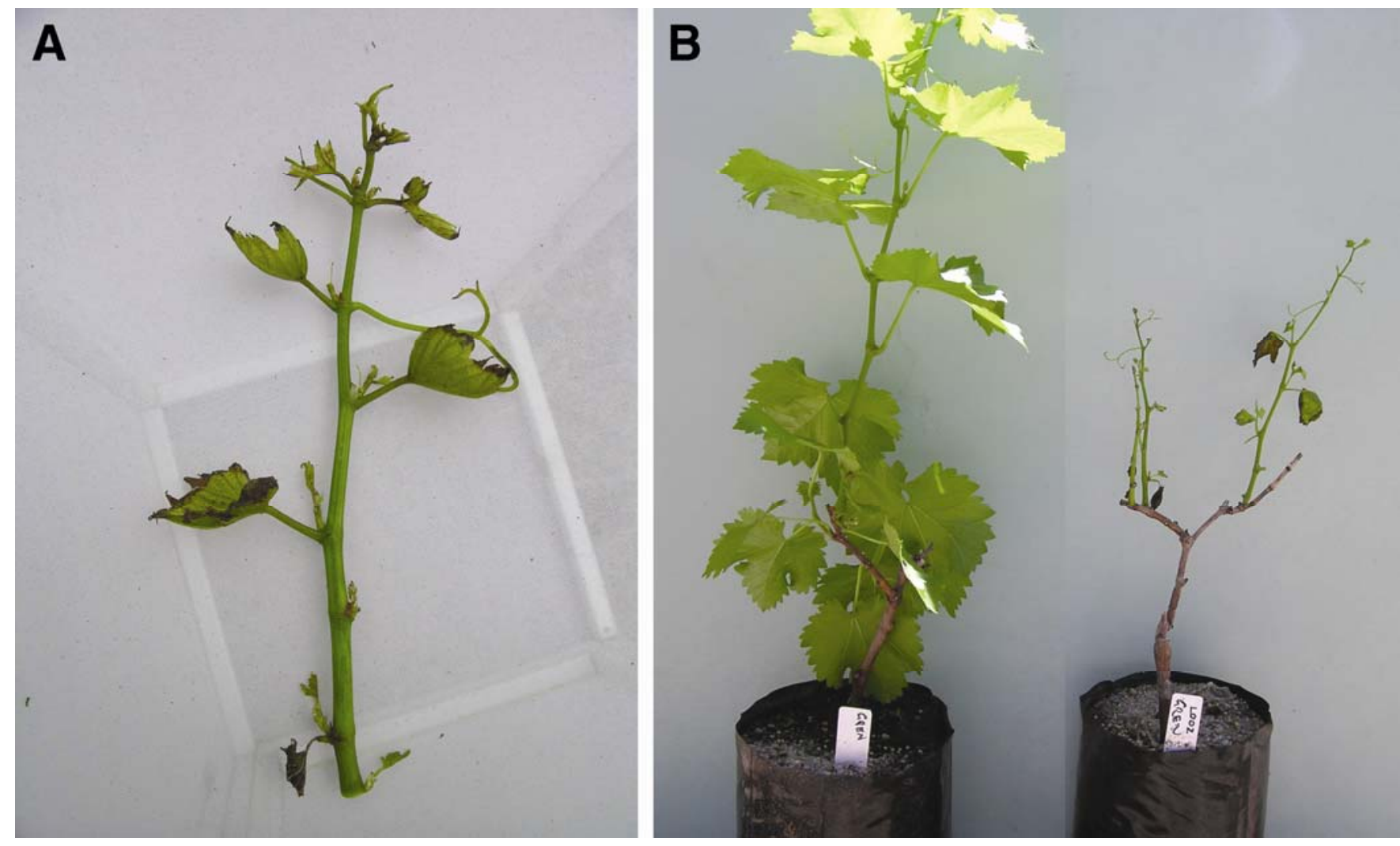

Fig. 1. Foliar symptoms on grapevine rootlings (Vitis vinifera cv. Grenache) 8 months after inoculation with potato dextrose agar plugs containing mycelia of Eutypa lata, showing A, stunted shoots and chlorotic, cupped leaves with tattered margins and $\mathbf{B}$, uninoculated control grapevine (left) compared with a symptomatic grapevine. 
When the second assessment was made, 20 months after inoculation, 24 of the 28 isolates used in experiment 1 (all except C002, MA101, OR022, and OR024) had induced foliar symptoms on Grenache grapevines, with symptom severity ranging from 2 to $36 \%$ (Fig. 2B). Insufficient data were obtained from isolations from grapevines inoculated with isolate B004 for statistical analysis. In experiment 2, 7 of the 12 isolates of E. lata induced foliar symptoms after 20 months. Only one isolate (SS10) induced symptoms on all three cultivars at this time and six isolates induced symptoms on Grenache only (Fig. 3B). Foliar symptoms were significantly more severe $(P<0.05)$ on Grenache $(8.9 \%)$ than on Cabernet Sauvignon $(0.5 \%)$ or Merlot $(1.2 \%)$ grapevines; however, no significant difference was observed among isolates. After 20 months, foliar symptoms were observed on shoots below the inoculation site on three grapevines in experiment 1 and on no grapevines in experiment 2 . Isolates which in- duced symptoms below the inoculation site were WB031, B003, and C001.

Destructive sampling of rootlings from four replicates of each experiment showed that, in experiment 1 , staining attributed to E. lata extended between 20 and $140 \mathrm{~mm}$ below the inoculation site 24 months after inoculation, depending on the isolate (Fig. 4). Mycelium of each isolate was recovered from all inoculated cuttings following plating of stem sections onto agar. Depending on the isolate, a mean distance of between 4 and $146 \mathrm{~mm}$ of grapevine stem (above and below the inoculation site) was colonized over the 24-month period, with a maximum of $230 \mathrm{~mm}$ observed in one replicate (inoculated with isolate MA089). Statistical analysis revealed significant differences $(P<0.05)$ among isolates for both symptom severity and growth rate. However, there was no relationship between the length of wood colonized and the severity of foliar symptoms $\left(R^{2}=\right.$ $0.13)$. There was a significant effect $(P<$ 0.05 ) of region on foliar symptom severity, with isolates from the Barossa Valley, Loxton, and Eden Valley inducing more severe foliar symptoms than those from Clare, McLaren Vale, and Coonawarra. However, no regional effect was evident for colonization by mycelium of $E$. lata. Nine isolates of $E$. lata grew ahead of the stain by a mean distance of between 5 and $40 \mathrm{~mm}$ over 24 months, with a maximum distance of $67 \mathrm{~mm}$ recorded in advance of the stain in one replicate (inoculated with isolate MA002).

The extent of staining attributed to $E$. lata and non- $E$. lata isolates and the spread of mycelium of the 12 isolates of E. lata (above and below the inoculation site) in experiment 2 is illustrated in Figure 5. Staining occurred on stems inoculated with each fungal species as well as the control (treated with a blank agar plug). In grapevines inoculated with $E$. lata, the average rate of spread of staining below the inoculation site ranged from 0 to 32,0 to 90 , and 16 to $104 \mathrm{~mm}$ after 24 months in Cabernet Sauvignon, Merlot, and Grenache, respec-

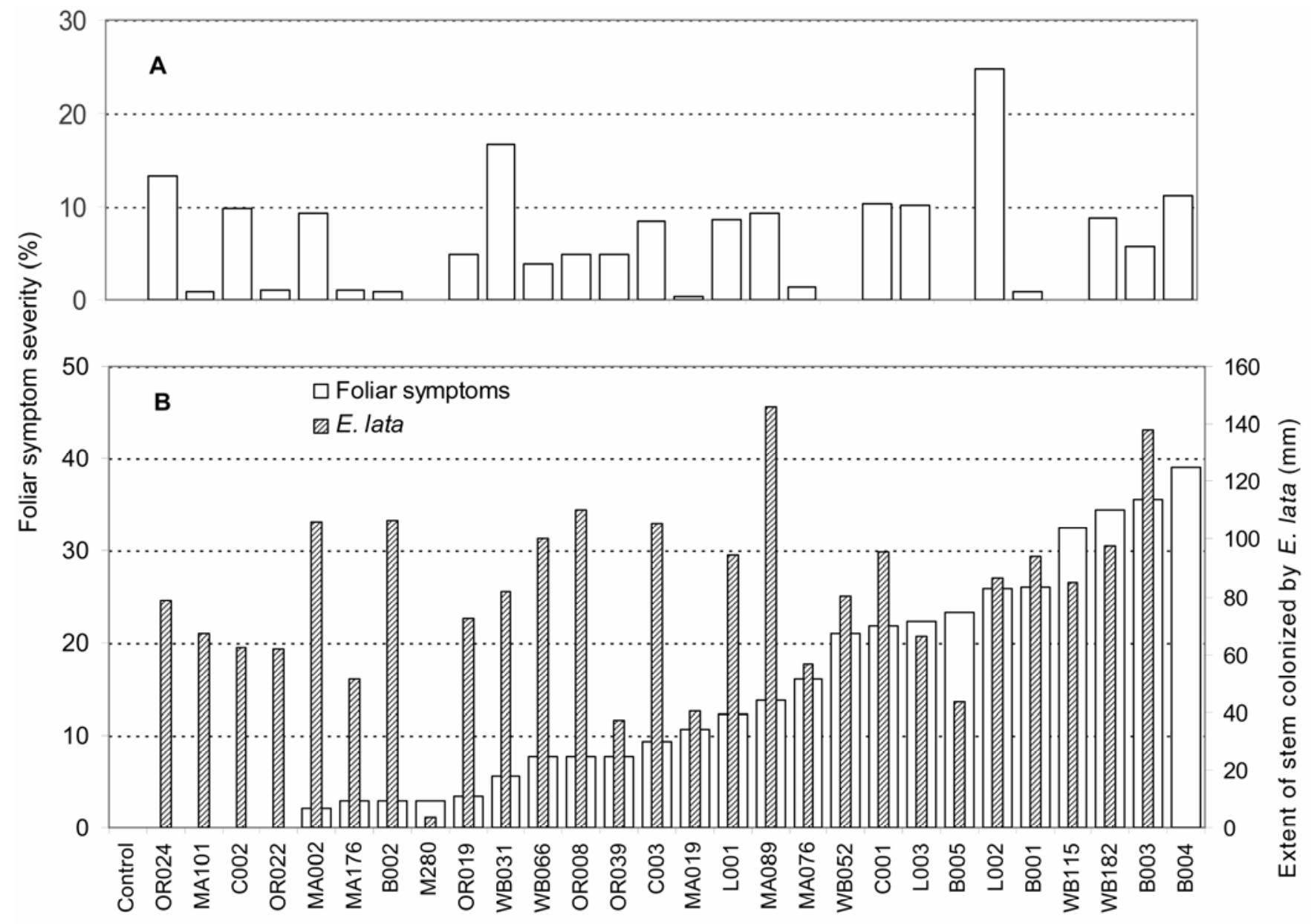

\section{E. lata isolates}

Fig. 2. Comparison of mean severity of foliar symptoms (the difference in length of stunted shoots on inoculated and control rootlings as a percentage of the length of shoots on control rootlings, \%) in experiment 1 on Grenache grapevines A, 8 and $\mathbf{B}, 20$ months after inoculating eight replicate grapevines with one of 28 isolates of Eutypa lata. B, The total length of stem colonized by mycelium of Eutypa lata (above and below the inoculation site) in four replicates destructively sampled 24 months after inoculation also is shown. No isolation data obtained for isolate B004. Controls were treated with a sterile agar plug. Least significant difference at $P<0.05\left(\mathrm{LSD}_{0.05}\right)$ (foliar symptoms at 8 months) $=15, \mathrm{LSD}_{0.05}$ (foliar symptoms at 20 months) $=27$, and LSD $0.05($ extent of $E$. lata at 24 months $)=72$. 
tively. There was significantly more staining in wood of Grenache than of the other two cultivars $(P<0.05)$; however, no differences were observed among isolates. In Cabernet Sauvignon and Merlot grapevines, most isolates colonized canes in advance of the staining; however, only five isolates did so in Grenache grapevines (Fig. 5). After 24 months, mycelium was isolated a maximum of 46,35 , and $34 \mathrm{~mm}$ beyond the stained tissue in Cabernet Sauvignon, Merlot, and Grenache grapevines, respectively. The single replicate from which E. lata was isolated furthest beyond staining was $80 \mathrm{~mm}$ in Grenache (inoculated with isolate 83330). The average distance at which mycelium of $E$. lata was isolated below the inoculation site over 24 months was 0 to 68,0 to 58 , and 0 to 82 $\mathrm{mm}$ for Cabernet Sauvignon, Merlot, and Grenache, respectively. There was no difference among cultivars in the extent of colonization by mycelium of E. lata, although there were significant differences $(P<0.05)$ among isolates.

Of the four replicates assessed for colonization by $E$. lata in both experiments, foliar symptoms were observed on shoots below the inoculation site in four cases over both years combined. In each case, mycelium of $E$. lata was isolated from between 127 and $195 \mathrm{~mm}$ below the inoculation site.

Field experiment. No foliar symptoms were observed within 3 to 4 years after the mature grapevines were inoculated with $E$. lata. Between 11 and 143 spurs were inoculated for each cultivar and the percentage of inoculated spurs from which $E$. lata was identified using DNA markers ranged from 41 to $91 \%$ (Table 2). The spread of staining attributed to E. lata differed significantly among cultivars, ranging from 10 mm/year (cvs. Merlot, Gamay, Grenache, and Semillon) to $18 \mathrm{~mm} /$ year (cvs. Cabernet Sauvignon and Shiraz). There was considerable variation in the amount of staining within cultivars and, in some cases, staining attributed to E. lata extended as much as $50 \mathrm{~mm} /$ year in cvs. Cabernet Sauvignon and Shiraz (data not shown).

\section{DISCUSSION}

In the shadehouse, distinctive foliar symptoms of Eutypa dieback developed on rooted grapevines within 8 months of inoculation. In comparison, Péros and Berger (19) reported characteristic symptoms within 4 weeks of inoculation of nonrooted cuttings, but attempts to repeat that experiment were unsuccessful (M. Creaser, personal communication, and S. John, personal communication). The initial results confirm the suggestion by Péros and Berger (19) that isolates of E. lata vary in their ability to induce foliar symptoms of Eutypa dieback on grapevines. The observation that Grenache displayed greater incidence and severity of disease than
Cabernet Sauvignon or Merlot confirms previous reports of high disease incidence in Grenache $(5,10)$.

Some isolates of E. lata induced foliar symptoms on Cabernet Sauvignon or Merlot grapevines after 8 months, but on Grenache grapevines only after 20 months (e.g., isolates N04, M302, 1776, and 200/3). Young grapevines of some cultivars (Cabernet Sauvignon and Merlot) may show symptoms faster than others (Grenache), but outgrow the symptoms over time. Foliar symptoms of Eutypa dieback have been observed to vary between seasons (21) and climatic fluctuations may contribute to this phenomenon. Therefore, it is possible that climate influenced host susceptibility of certain isolates to induce symptoms in the shadehouse trial.

The severity of foliar symptoms appeared to be related to origin of the isolates, which may reflect variation in virulence. For example, the Barossa Valley has a long history of apricot production and Eutypa dieback. In general, Barossa Valley, Eden Valley, and Loxton are warmer and drier than Coonawarra, McLaren Vale, and Clare. It may be that isolates from the former three regions were better suited to the intermediate climatic conditions at the trial site.

The toxic metabolites responsible for the foliar symptoms of Eutypa dieback generally are believed to be transported

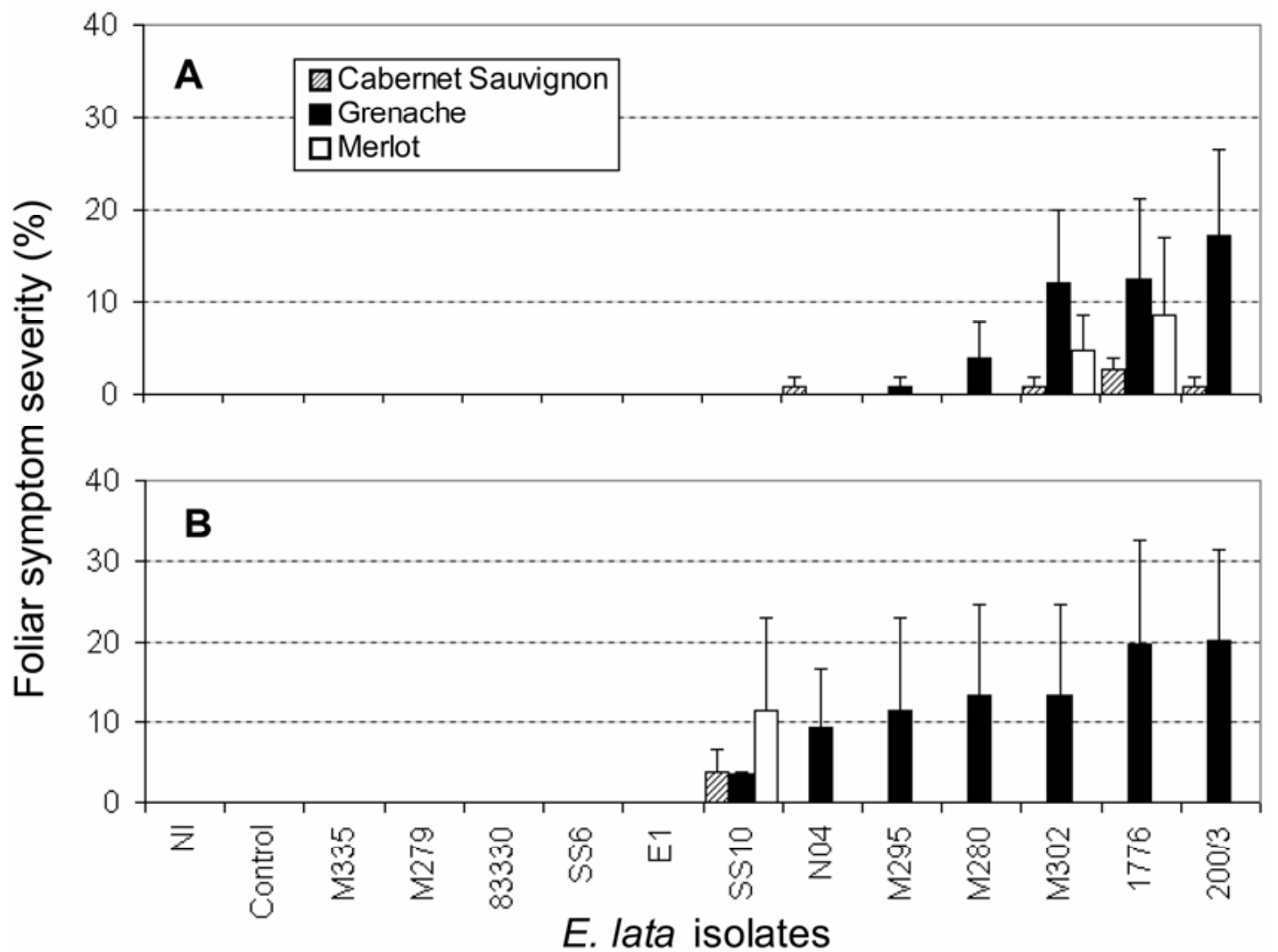

Fig. 3. Mean severity of foliar symptoms (the difference in length of stunted shoots on inoculated and control rootlings as a percentage of the length of shoots on control rootlings, \%) on grapevines in experiment 2 in the shadehouse A, 8 and B, 20 months after inoculation with a range of Eutypa lata isolates. Controls were treated with a sterile agar plug. NI = noninoculated grapevines. Bars represent standard error of the mean (eight replicates per treatment). 
upward through the xylem tissue (1). However, the appearance of symptoms on shoots arising from below the inoculation site indicates that such metabolites may be translocated in both directions, or that mycelium has colonized the wood below the inoculation point much more rapidly than expected. Assessment of mycelial growth was conducted 24 months after inoculation; therefore, we were unable to determine whether $E$. lata mycelium had extended below the symptomatic shoots 8 months after inoculation. This observation may be an artifact of the experimental conditions and further research is necessary. If not, there may be implications for disease management where grapevines are cut back and new shoots trained to replace the excised growth but infected tissue is not completely removed. Therefore, new shoots which are trained from below infected wood may still be at risk of foliar symptom development. Mahoney et al. (13) suggested that the toxic metabolites of E. lata react at the point of production, disrupting the vascular structure and inhibiting transport of nutrients, rather than being translocated to symptomatic tissue.
The expression of foliar symptoms on shoots below colonized wood, as seen in this study, does not support this hypothesis.

The absence of foliar symptoms on mature grapevines is consistent with past studies reporting that the delay between infection and symptom expression may be up to 8 years (22). Young grapevines may express symptoms more readily than mature grapevines, or the environmental conditions in the shadehouse may have been more conducive to symptom expression than those in the field. However, given that naturally infected grapevines in blocks adjacent to the field trial did display foliar symptoms throughout the course of the trial, the absence of symptoms is likely due to the time required for the fungus to establish in the grapevine and start producing toxic metabolites. Furthermore, the mycelial inoculation of immature grapevines in the shadehouse may have contributed to the rapid expression of symptoms compared with the ascosporic inoculation of mature grapevines in the field. In any event, the shadehouse technique reported in this article provides a rapid and effective technique for further studies with $E$. lata infection of grapevines.

Although Grenache displayed considerably more severe foliar symptoms than Merlot or Cabernet Sauvignon in the shadehouse, this study suggested that Cabernet Sauvignon has a tolerance similar to Merlot, which is not consistent with past reports $(5,10)$ or with field observations. It is possible that the differences in susceptibility among cultivars in the shadehouse may, in part, reflect the immaturity of the tissue, which was 18 months old when inoculated. As the wood ages, differences in susceptibility between Cabernet Sauvignon and Merlot may become more apparent.

The growth rate of E. lata in Grenache cuttings in the shadehouse varied significantly among isolates and, although there was an apparent effect of geographic origin on foliar symptom expression, there was no such effect for spread of the fungus in the wood. Furthermore, there was no obvious relationship between the growth rate of E. lata in the wood and its ability to induce foliar symptoms. Susceptibility to expression of foliar symptoms appeared to

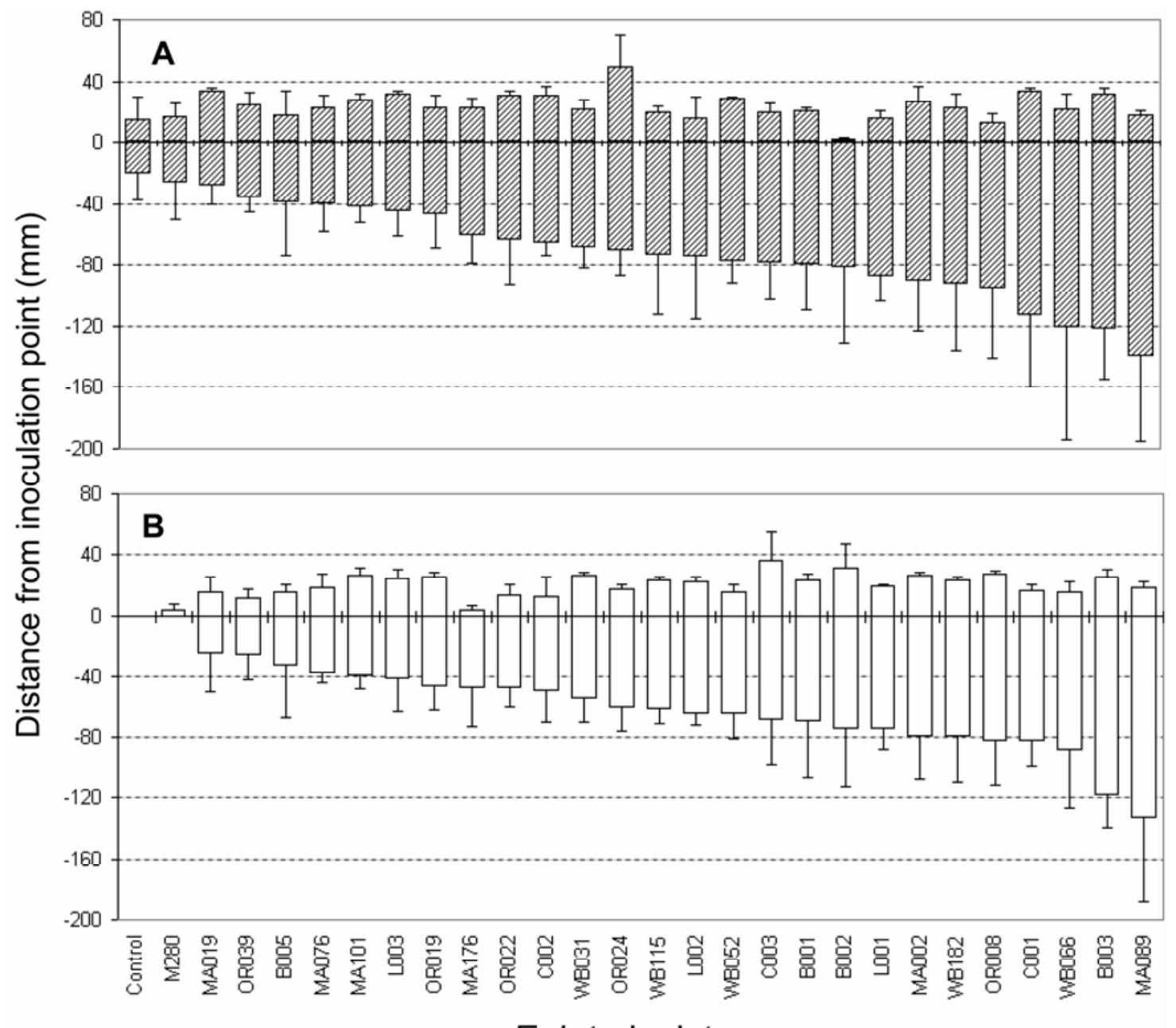

\section{E. lata isolates}

Fig. 4. A, Extent of staining and B, colonization by Eutypa lata isolates above and below (-) the inoculation point (0) on stems of Grenache in experiment 1 in the shadehouse, 24 months after inoculation. Controls were treated with a blank agar plug. Data for staining and colonization represent means of four replications. Bars represent standard error of the mean. 
be correlated with wood staining but not with the growth rate of the fungus in infected wood. This correlation may be because isolates which induce foliar symptoms also produce more cytotoxic enzymes which degrade and stain woody tissue, or that phenolic compounds produced by the plant in the vicinity of the infection are oxidized, contributing to vascular staining. However, control grapevines wounded and treated with blank agar plugs also exhibited some staining, as did grapevines inoculated with other species of woodinhabiting fungi, including Phaeomoniella chlamydospora, Phaeoacremonium aleophilum, Botryosphaeria spp., Libertella spp., and Fomitiporia spp. This suggests that wood staining may, in part, be caused by factors other than E. lata, such as a wound response. The biochemical changes that result in staining require investigation.

The maximum distance at which mycelium of E. lata was detected ahead of stained wood in the shadehouse experiment was $80 \mathrm{~mm}$; this may be a "worst case scenario" because the growth rate of the fungus in mature grapevines is slower. Therefore, to manage Eutypa dieback in established vineyards, growers should cut at least $10 \mathrm{~cm}$ beyond the last sign of staining to ensure removal of the fungus. This confirms previous recommendations of cutting 10 to $20 \mathrm{~cm}$ beyond any stained tissue $(7,9)$. These data represent 2 years of fungal growth in the wood and it is important to determine whether the distance between discoloration and the hyphal front changes with time.

Mycelium of E. lata spread more rapidly down than up the stem in the shadehouse; however, it was interesting to note that mycelium could grow upward because it generally is considered that mycelium spreads down the grapevine only. Because there was no evidence of this found in the literature, this study is the first report of mycelial growth of E. lata in both directions. There are no data to confirm whether the pathogen grows in both directions in mature vines, and this should be investigated. This may have implications for disease management of spur-pruned grapevines because infection in one cordon may lead to infection of the other cordon.

Wood staining attributed to necrosis caused by E. lata progressed at 10 to 18 $\mathrm{mm} /$ year in mature field grapevines. When compared with the spread of staining on cuttings in the shadehouse, Merlot was similar at $8 \mathrm{~mm} /$ year, but Cabernet Sauvignon and Grenache progressed at 4 and 22 $\mathrm{mm} / \mathrm{year}$, respectively. This may reflect the small sample size of eight spurs from Grenache that yielded E. lata compared with 16 to 80 spurs of the other cultivars in

Table 2. Annual rate of spread of stained wood in grapevine cultivars inoculated with Eutypa lata, via wounds on 1-year-old canes, in 2000 and 2001

\begin{tabular}{lcccc}
\hline Cultivar & $\begin{array}{c}\text { Year } \\
\text { planted }\end{array}$ & $\begin{array}{c}\text { No. of } \\
\text { inoculated canes }\end{array}$ & $\begin{array}{c}\text { Spurs with } \\
\boldsymbol{E} \text {. lata }(\boldsymbol{\%})\end{array}$ & $\begin{array}{c}\text { Rate of stain spread } \\
(\mathbf{m m} / \mathbf{y e a r})^{\mathbf{z}}\end{array}$ \\
\hline Cabernet Sauvignon & 1984 & 49 & 47 & $18.6 \mathrm{a}$ \\
Shiraz & 1988 & 85 & 62 & $18.6 \mathrm{a}$ \\
Pinot Noir & 1976 & 47 & 47 & $15.7 \mathrm{ab}$ \\
Riesling & 1988 & 62 & 53 & $12.5 \mathrm{~b}$ \\
Semillon & 1989 & 45 & 91 & $10.8 \mathrm{c}$ \\
Grenache & 1991 & 11 & 72 & $10.2 \mathrm{c}$ \\
Gamay & 1988 & 143 & 56 & $10.1 \mathrm{c}$ \\
Merlot & 1985 & 43 & 41 & $9.8 \mathrm{c}$ \\
\hline
\end{tabular}

${ }^{y}$ Spurs were harvested in 2004 for assessment by measurement of stained wood and analysis with an E. lata-specific DNA probe.

${ }^{\mathrm{z}}$ Values with the same letter are not significantly different $(P=0.05)$.

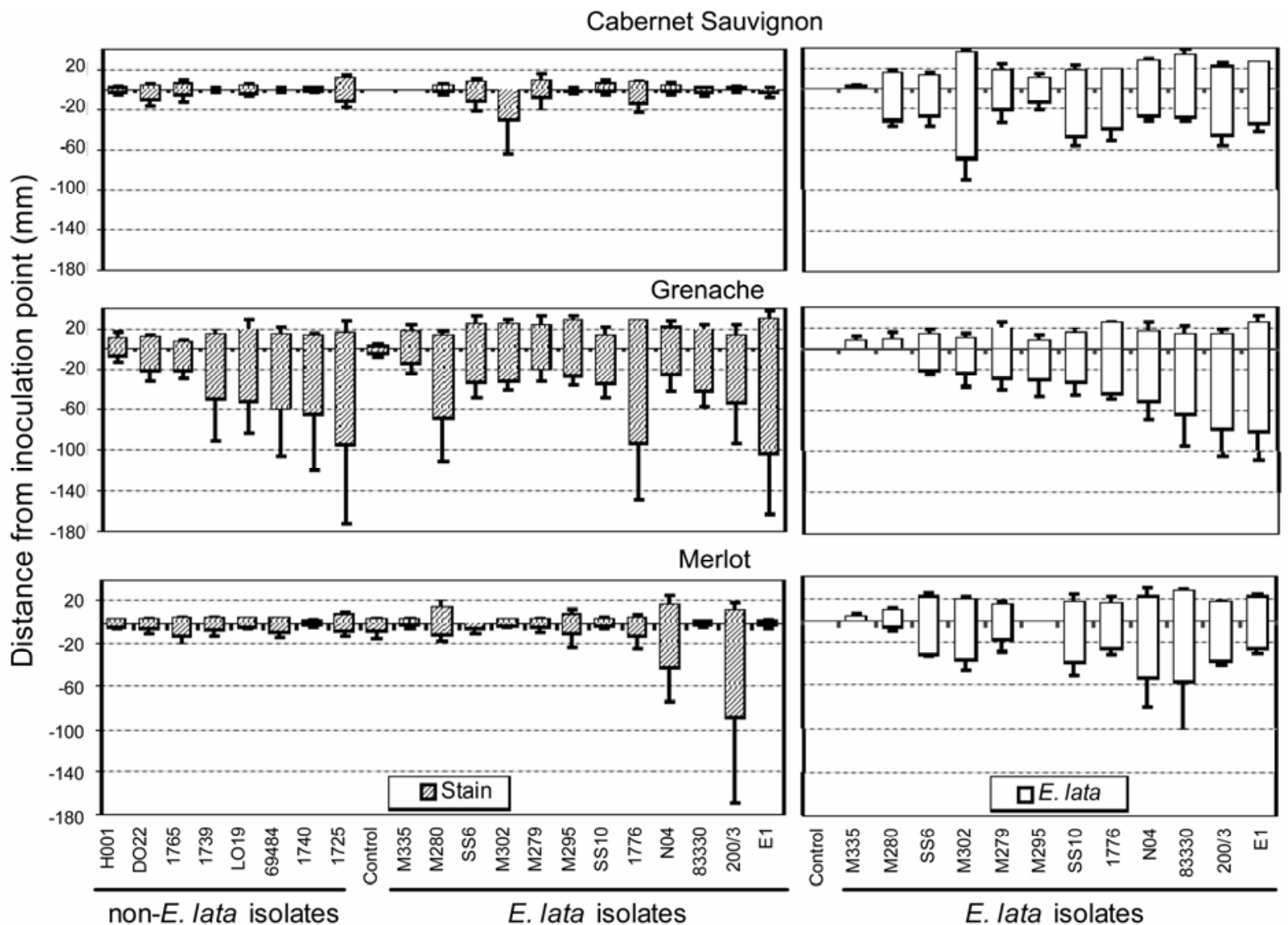

Fig. 5. Extent of staining (left) induced by Eutypa lata and non-E. lata isolates and colonization (right) by E. lata of canes of three grapevine cultivars in experiment 2 in the shadehouse, 24 months after inoculation. Negative values show colonization below the point of inoculation (0). Controls were treated with a sterile agar plug. Data for staining and colonization represent means of four replications. Bars represent standard error of the mean. 
the field. Also, cultivars may react differently to colonization by $E$. lata when younger rootlings are inoculated than when the grapevine is mature. Alternatively, the observation that Grenache, generally considered susceptible to Eutypa dieback, showed less staining than Pinot Noir (generally considered tolerant), may provide further evidence that the ability of $E$. lata to induce foliar symptoms is not linked to its ability to colonize the wood.

\section{ACKNOWLEDGMENTS}

This research was supported by the Commonwealth Cooperative Research Centre Program and conducted through the CRC for Viticulture with support from Australia's grapegrowers and winemakers through their investment body, the Grape and Wine Research and Development Corporation, with matching funds from the Federal Government. We acknowledge M. Creaser for establishing the field trial. We thank D. Sosnowski and T. Zanker for technical assistance; M. Creaser, M Carter, and M. Cole for providing fungal isolates for this study; Kemps Nurseries, Barmera, South Australia for providing rooted grapevine cuttings; and R. Walker (CSIRO Plant Industry, Merbein, Victoria) for reviewing this article.

\section{LITERATURE CITED}

1. Amborabe, B. E., Fleurat-Lessard, P., Bonmort, J., Roustan, J. P., and Roblin, G. 2001. Effects of eutypine, a toxin from Eutypa lata, on plant cell plasma membrane: Possible subsequent implication in disease development. Plant Physiol. Biochem. 39:51-58.

2. Baker, K. F. 1957. The U.C. System for Producing Healthy Container-Grown Plants. University of California Press, Berkeley.

3. Carter, M. V. 1960. Further studies on Eutypa armeniacae Hansf. \& Carter. Aust. J. Agric.
Res. 11:498-504.

4. Carter, M. V. 1978. Eutypa dieback ("dying arm") disease of vines-progress towards control. Aust. Grapegrower Winemaker 172:27-28.

5. Carter, M. V. 1991. The status of Eutypa lata as a pathogen. Monograph-Phytopathological Paper No. 32. International Mycological Institute, Surrey, U.K.

6. Creaser, M., and Wicks, T. 2001. Yearly variation in Eutypa dieback symptoms and the relationship to grapevine yield. Aust. N. Z. Grapegrower Winemaker 452:50-52.

7. Creaser, M. L., and Wicks, T. J. 2002. Eutypa dieback. Page 15 in: IPM ViticultureResearch to Practice Training Manual, 5th ed. D. Braybrook, A. Shanks, D. Aitken, and G. Hogan, eds. Cooperative Research Centre for Viticulture, Glen Osmond.

8. Dubos, B. 1987. Mise au point sur les maladies de dépérissement dans le vignole français. Prog. Agric. Vitic. 104:135-140.

9. Emmett, R. W., and Magarey, P. A. 2003. Eutypa dieback. Pages 28-30 in: Diseases and Pests. P. Nicholas, P. Magarey, and M. Wachtel, eds. Winetitles, Adelaide, Australia.

10. Highet, A., and Wicks, T. 1998. The incidence of Eutypa dieback in South Australian vineyards. Aust. Grapegrower Winemaker 441a:135-136

11. John, S., Wicks, T. J., Hunt, J. S., Lorimer, M.F., Oakey, H., and Scott, E. S. 2005. Protection of grapevine pruning wounds from infection by Eutypa lata using Trichoderma harzianum and Fusarium lateritium. Australas. Plant. Pathol. 34:569-575.

12. Lardner, R., Stummer, B. E., Sosnowski, M. R., and Scott, E. S. 2005. Molecular identification and detection of Eutypa lata in grapevine. Mycol. Res. 109:799-808.

13. Mahoney, N., Molyneux, R. J., Smith, L. R., Schoch, T. K., Rolshausen, P. E., and Gubler, W. D. 2005. Dying-arm disease in grapevines: Diagnosis of infection with Eutypa lata by me- tabolite analysis. J. Agric. Food. Chem. 53:8148-8155.

14. Moller, W. J., and Kasimatis, A. N. 1978. Dieback of grapevines caused by Eutypa armeniacae. Plant Dis. Rep. 62:254-258.

15. Moller, W. J., and Kasimatis, A. N. 1981 Further evidence that Eutypa armeniacae - not Phomopsis viticola - incites dead arm symptoms on grape. Plant Dis. 65:429-431.

16. Munkvold, G. P., Duthie, J. A., and Marois, J. J. 1994. Reductions in yield and vegetative growth of grapevines due to Eutypa dieback. Phytopathology 84:186-192.

17. Munkvold, G. P., and Marois, J. J. 1995. Factors associated with variation in susceptibility of grapevine pruning wounds to infection by Eutypa lata. Phytopathology 85:249-256.

18. Pascoe, I. 1999. Grapevine trunk diseasesblack goo decline, esca, Eutypa dieback and others. Aust. Grapegrower Winemaker 429:2428.

19. Péros, J. P., and Berger, G. 1994. A rapid method to assess the aggressiveness of Eutypa lata isolates and the susceptibility of grapevine cultivars to Eutypa dieback. Agronomie 14:515-523.

20. Siebert, J. B. 2001. Eutypa: the economic toll on vineyards. Wines Vines April:50-56.

21. Sosnowski, M., Shtienberg, D., Creaser, M., Wicks, T., Lardner, R., and Scott, E. 2005. Unlocking the secrets of annual variation in Eutypa dieback symptoms. Aust. N.Z. Grapegrower Winemaker 497a:7-12.

22. Tey-Rulh, P., Philippe, I., Renaud, J. M., Tsoupras, G., De Angelis, P., Fallot, J., and Tabacchi, R. 1991. Eutypine, a phytotoxin produced by Eutypa lata the causal agent of dying-arm disease of grapevine. Phytochemistry 30:471-473.

23. Wicks, T. 1975. The dying arm disorder of vines in South Australia. Agric. Rec. 2:14-20.

24. Wicks, T., and Davies, K. 1999. The effect of Eutypa on grapevine yield. Aust. Grapegrower Winemaker 426a: 15-16. 